鉱物学雑誌 第 11 巻 特別号第 1 号 1974 年 3 月

モンモリロナイトの風化物の数例について

\title{
Some examples of weathering product of montmorillonite
}

赫 井 純 治 (Junji Akai)*

は じめ に

てれまでカオリンーモンモリロナイト混合層鉱物として記載されている鉱物のうち （001）反射分需めてブロードなタイプの陚料は，多くの場合モンモりロ+イトが風化 の影響をうけて生成した産状を示している。モンモリロナイトは風化により変質して その鉱物学的性質を変え, それとともにカオリン鉱物が生成してくるが, てのモンモ リロ+イトの変化には (hk) 反射はシャープであるのに $(001)$ 反射がブロードにな るという特徵があり，ての過程における混合層鉣物生成の可能性および粘土鉣物の変 化をみるため，その風化過程を追ってみた。

\section{試料及び実験結果}

試料 T181, T185, T183 は知多半島の鮮新統常滑風群中に夾まれる火山灰層で, 乙の順に地表風化を強くうけている。不規則方位のX線回折データ(第 1 図)では未風 化のT181が dioctahedral 型のモンモリロ+イトであるのに対し, 風化物では (hk) 反射に比し (001) 反射が弱まり,また（06）の反射の半価幅が大きくなり二重線と

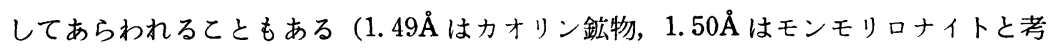
えられる)。定方位武料について種々の処理を行なったデータは第 2 図に示してあ る。湿った自然の状態を知るため武料採取より風乾させるととなく, 相対湿度 $100 \%$ (R. H. 100) の状態でX線照射すると風化物では $10 \AA$ の加水ハロイサイトのピークが 認められ, 乙れは風乾すると数分間で直ちに脱水して $7 \AA$ にうつる。風化物の風乾試

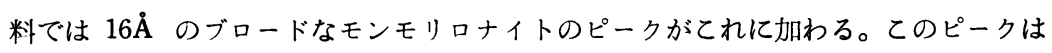
エチレングリコール処理で未風化のモンモリロナイトに比べやや面間隔が大きく, 硝 酸アンモニウム処理ではその縮み方が少なく, 加熱処理で未風化のものに比べ㐿閒水 の脱水にやや抵抗性を示す。風化物の示差熱分析曲線（第 3 図）は大略モンモリロナ 


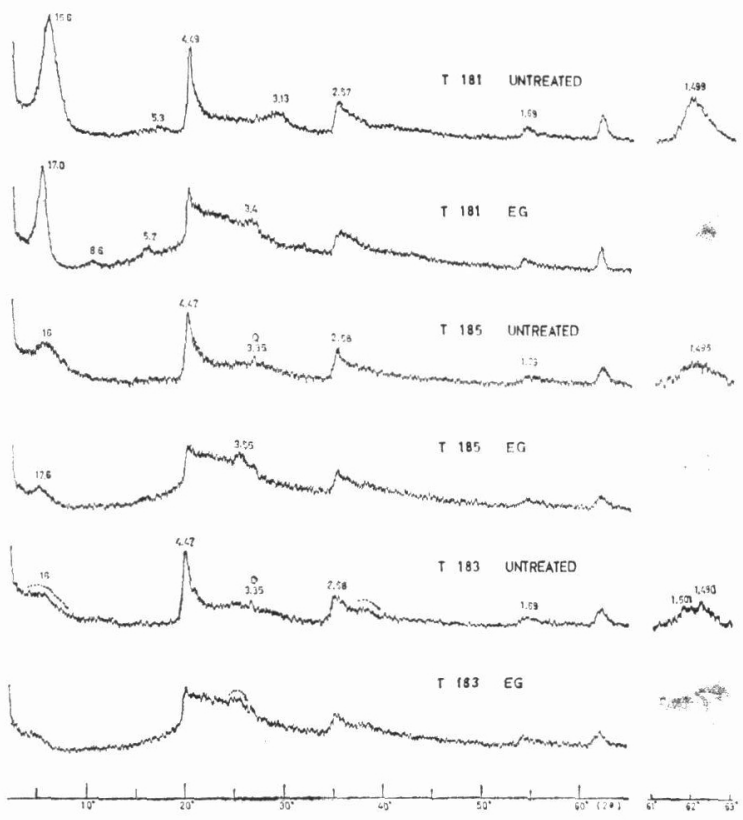

第1図知多半島産試料のX線回折図

イトの曲線とカオリン鉣物のそれが重なりあったものであり，さらに $320^{\circ} \mathrm{C} に$ 㤎めら れるごく小さなピークはギブサイトの吸熱ピークの位置と一致し，その存在が推定さ れる。風化物の加熱減量曲線（第 4 困）にはギブサイトの脱水による減量は明らかで

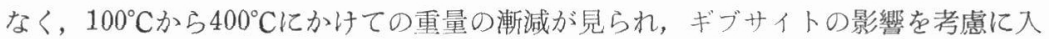
れたとしても粘土鉱物の層間水の脱水がより緩慢に行なわれているととが推定される。 電顕観察では第 5 図に示すように未風化の䟼料（T181）では edge のはっきりしな い不定形粒子からなり，乙れらの粒子の制限視野回折はリング状パターン（第6 図） を示すととが多いが diffuse な孤状のパターンを示すとともある。第7図（T183） に示すように風化の進行にともなって不定形粒子が減少し，代って薄い板状粒子が現 われ，乙れはさらに風化が十分進むと大きく厚くなり,量も増し，ての段階では何らか の溶液から物質が付加され板状精子が成長しているかの感じを与える。パイプ状の八 ロイサイト粒子はごくわずかしか存在しない。また風化で残った不定形粒子からの電 子線回折は第 8 図, 第 9 図Aに示すようにdiffuse な回折を与古ることが多い。てれ らは円周方向と b 軸方向とに diffuse する。前者は小さな結晶がある程度方位をそろ えつつあるととに対応し，後者は粘土粒子の彎曲によると考兑られる。（第 9 図 B 参 


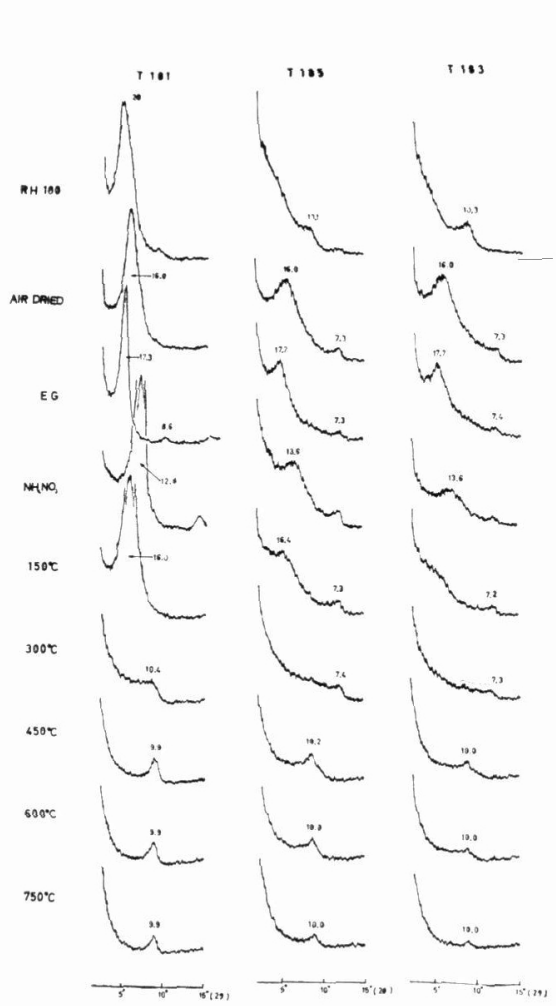

第 2 図知多半島産試料の定方位 $\mathrm{X}$ 線 回折図

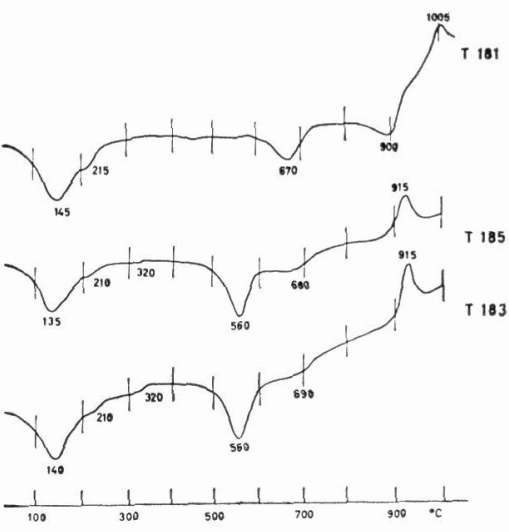

第3 図 知多半島産試料の示差熱分 析曲線

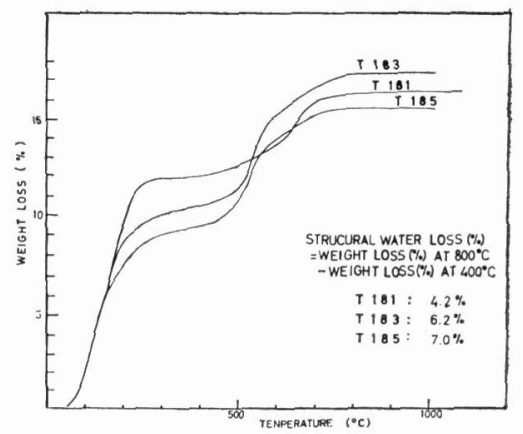

第 4 図 知多半島産試料の加熱減量 曲線

照)。またてのタイプのパターンには（20）の diffuse な弧状の反射が半径方向に split して二重弧となっている場合（第 9 図A）もある。この原因は不明である。ま た diffuse な弧の央にスポットが見られること（第10図）もあり，この種の回折像に はかなりの多様性がある。板状粒子からはシャ一プなスポットパターン(多くはカ才 リンと考えられる)，あるいはスポットとリングの複合したパターンが方つう得られ， 後者はさらにスポットとリングが同一面間隔を示すものとスポットがより大きな面間 隔を示す場合（第11図）があり，乙の時はスポットがモンモリロナイトの面間隔(1.5

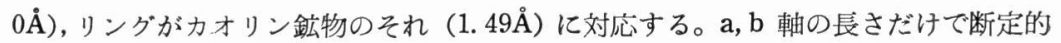




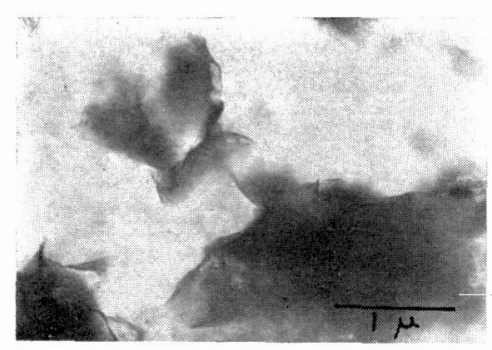

第 5 図 未風化試料（T 181）

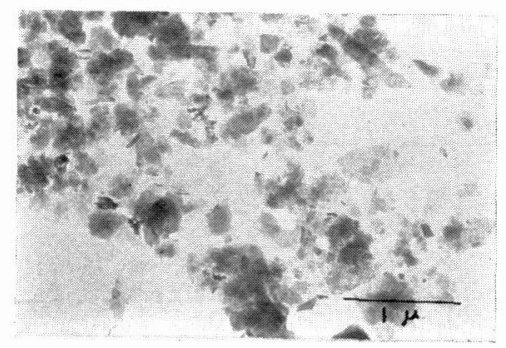

第 7 図 風化物（ $\mathrm{T}$ 183）
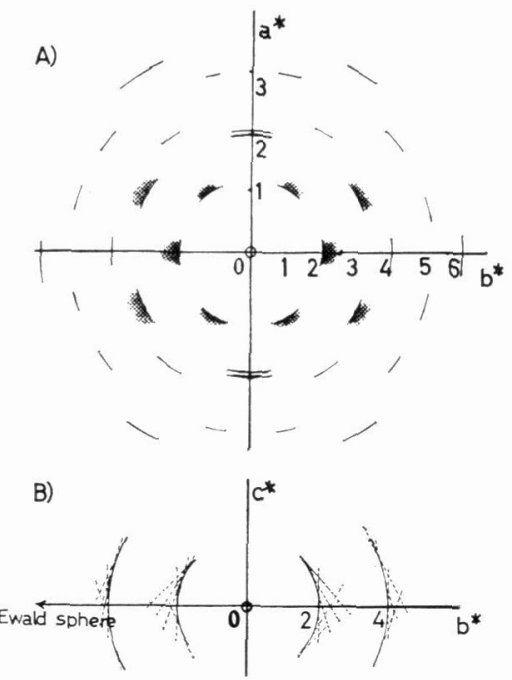

第 9 図 A : 不定形粒子回折図( $\mathrm{T} 183$ ) $\mathrm{B} ： \mathrm{~b}$ 軸方向への diffuse の説 明。破線は逆格子棒を示す。

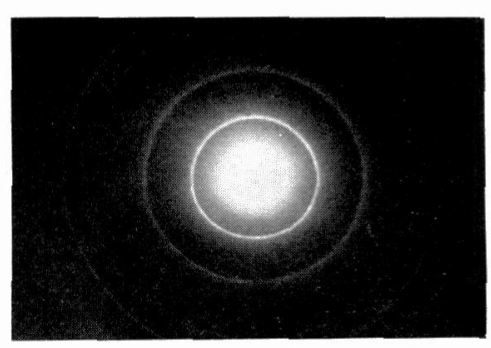

第6図 不定形䊉子回折像（T 181）

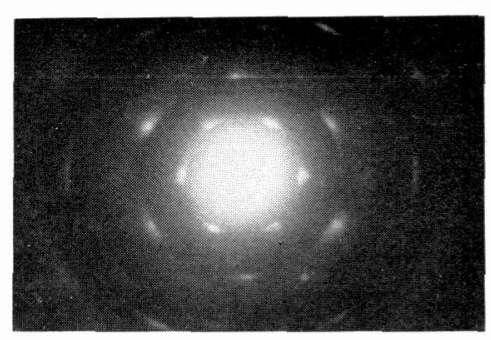

第 8 図 不定形粘子回折像（ $T$ 183）

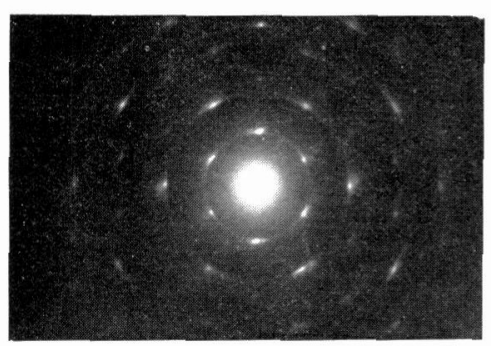

第10図 不定形粒子回折像（T 183）

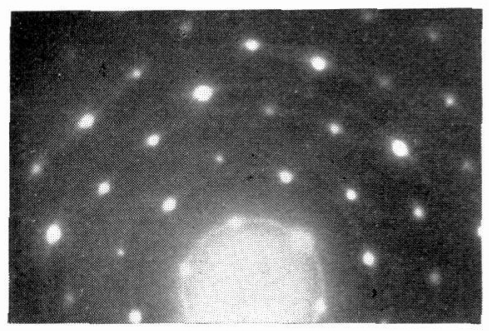

第11図 板状粒子回折像（T 183） 


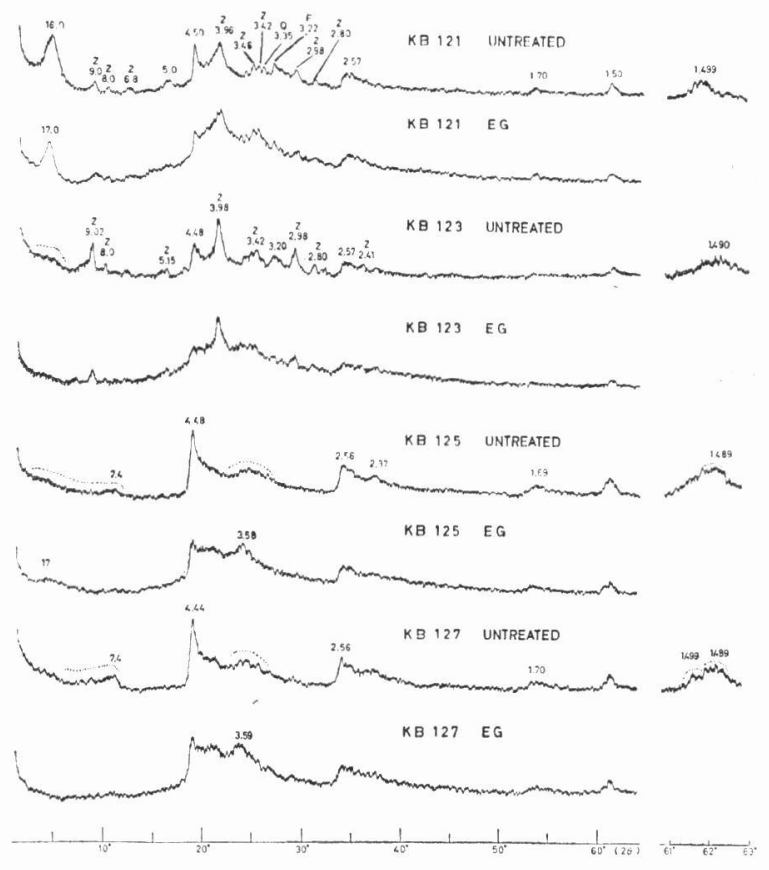

第12図三木才産試料，X線回折図

なととはいえないが，乙れがそれ尽れモンモリロナイト，カオリン鉱物とすると，方 向性のそろったベースのモンモりロナイトにランダムに小結晶粒子のカオリン鉣物が 多数生成していることが考えられるパターンである。またての風化過程を通じて非晶 質物質はあまり見あたらなかった。

次にもう一例, 兵庫祘三木市の中新統神开層群中の白色火山灭首の風化物 (KB123, KB125，KB127）についてX線粉末図形のみ第12网に示す。未風化試料 (KB121) は モンモリロナイトとシャブチロルフッ石（Z）とからなる。風化によるモンモリロナ イトの変化，カオリン鉱物生成の様子は上述の知多半島産のものと同一傾向を示す。

\section{考察とまとめ}

1. 風化によりモンモリロ+イトは，X線および熱分析のデータに見られたように層 間の性質を変化させる。

2. X線的にこのような $(001)$ 方向の変化にもかかわらず (hk) 方向には変化がみ られず，風化過程で (hk) 方向には構造的に安定で一時期全くの非晶質の状態をへて 
カオリン化することはないように思われる。

3. 風化の進行とともにカオリン鈗物として加水ハロイサイトが生成してくるが，乙 れは板状粒子の中に生成していると考えられる点，メタハロイサイトへの極めて容易 な脱水など, 特異な性質を有する。

4. このカオリン鉱物生成の初期には，混合首をなすかどうかは不明だがモンモリ口 ナイトの構造を何らかの形で引きついで生成したてとが考えられ, 同一粒子の中にモ ンモリロナイト風とカオリン風が共存している可能性がある。第11図の同折パターン は Sudo and Hayashi（1956）の示したモデルの粒子に対応するものかもしれない。 5. 電子線回折による変化の追跡は，風化物における diffuseなパ多ンン，スボット パターンの増加にみられるように全体として，またモンモりロナイト粒子においても よりスポット的要系が多くなり（hk）方向の配问性がよくなる傾问を六す。また風化 物では粒子毎にパターンが微紐な点で異なることが多く，かなりの多様性をもってく る。このうち diffuse なパターンを与える粒子の具体的な配向状態を格子像解像法で 解明するため, 現在検討中である。

6. 今回検討の試料では, 変化過程で多くの粒子が明瞭な混合風構造をへて変化する ということは認められず，X線的には主に混合物である。ただ上述の 4 の点の具体的 検討，およびブロードな $(001)$ 反射と，シャープな (hk) 反射の対泣の構造上の意味 の解明は今後に残された閏題の一つである。今後西接高分解能電顕像で，てれらの構 造に関する情報が得られるてとが期街される。

謝 辞本研究にあたって助豈いただいた京都大学上田健夫助教授, 冨田克敏氏, ならびに電子顕微顕鏡に関して終始ご指導いただいた京都大学化学研究所植田夏助教 授, 吉田募氏に心から感謝の意をささげる。

\section{文献}

1) Altshuler, Z. S. et al. (1963) Science, 141, 148-152.

2) Shimoyama, A. (1969) Proc. Internat. Clay. Conf. Tokyo, 225-231.

3) Sudo, T. and Hayashi, H. (1956 a) Clays and Clay Min., 4, 389-412.

4) Sudo, T. and Hayashi, H. (1956 b) Nature, 178, 1115-1116. 